\title{
SOME MOISTURE DEPENDENT THERMAL PROPERTIES AND BULK DENSITY OF Prosopis Africana SEEDS (OKPEYE)
}

\author{
F. U. Asoiro' ${ }^{1, *}$ and C. J. Ohagwu² \\ 1,2, DEPARTMENT OF AGRICULTURAL AND BIORESOURCES ENGINEERING, UNIVERSITY OF NiGERIA, NSUKKA, NIGERIA \\ Email addresses: ${ }^{1}$ felix.asoiro@unn.edu.ng, ${ }^{2}$ chukwuemeka.ohagwu@unn.edu.ng
}

\begin{abstract}
The thermal heat conductivity, specific heat capacity, thermal heat diffusivity and bulk density of Prosopis africana seeds were determined as a function of moisture content. Specific heat capacity was measured by the method of mixture while the thermal heat conductivity was measured by the guarded hot plate method. Thermal heat diffusivity was calculated from the experimental results obtained from specific heat capacity, thermal heat conductivity and bulk density. The bulk density for Prosopis africana (PA) seeds decreased from $890 \mathrm{~kg} \mathrm{~m}^{-3}$ to $590 \mathrm{~kg} \mathrm{~m}^{-3}$ as moisture content increased from 4 to $20 \%$ wet basis (w.b). Specific heat capacity increased from $2760 \mathrm{~J} \mathrm{~kg}^{-1}{ }^{\circ} \mathrm{C}^{-1}$ to $2960 \mathrm{~J} \mathrm{~kg}{ }^{-1}{ }^{\circ} \mathrm{C}^{-1}$ with increasing moisture content. The thermal heat conductivity ranged between 0.70 and $0.90 \mathrm{~W} \mathrm{~m}^{-10} \mathrm{C}^{-1}$ when moisture content rose from $4 \%$ to $20 \%$ (w.b). Thermal heat diffusivity increased from $2.7 \times 10^{-7}$ to $4.2 \times 10^{-7} \mathrm{~m}^{2} \mathrm{~s}^{1}$ as moisture content increased from 4 to $20 \%$ (w.b). The values obtained for these thermal properties and bulk density could be useful for design of systems for heat treatment of Prosopis africana seeds.
\end{abstract}

Keywords: Prosopis africana, okpeye seeds, thermal heat conductivity, specific heat capacity, thermal heat diffusivity, bulk density.

\section{INTRODUCTION}

Prosopis africana also known as African mesquite or iron tree is the only species of Prosopis that is indigenous to tropical Africa. Its tree could be between $4-20 \mathrm{~m}$ long. This tree is characterized by a deep, fast-growing tap root. Prosopis africana (PA) is mostly found growing in the savanna regions of western Africa [1 - 4]. It has different names by the various ethnic groups in Nigerian. PA is the only species found in the savanna, especially in Senegal and Nigeria. Because this species is not cultivated, it is often referred to as wild, endangered but edible [5], as a lost crop or as a lesser crop [6]. PA has vast social, economic, cultural, medicinal and agricultural values. It is widely used and consumed in the entire country and beyond. It is very popular for its seeds, highly priced food condiment or seasoning, rich in protein, fatty acids and other vital nutrients and minerals $[7,8,9,10]$. Despite the huge importance, high consumption rate and the potential use of PA as a good source of foreign earnings for Nigeria, the traditional method of post harvest processing provides a poorquality product with low nutrient content. This has limited its utilization both locally and internationally. In Nigeria, there is scarcely any large-scale producer of PA that use machinery for its storage, handling or processing. Many small-scale producers carry out these operations manually.

Knowledge of thermal properties of food substances is essential to researchers and designers in the field of food science for a variety of purposes. This include predicting the drying rate or temperature distribution within foods of various compositions and geometric shapes when subjected to different drying, heating and cooling conditions; mathematical modeling of different drying systems or designing of heat transfer equipment, dehydrating and sterilizing apparatuses. Such information is not always available.

The moisture content of agricultural materials greatly affects various thermal properties. Therefore, the thermal properties data at different moisture contents can be directly used to design/select and development of thermal, processing and storage systems [11]. Aviara et al. [12] noted that the moisture dependent characteristics of thermal properties have effect on the adjustment and performance of agricultural product processing machines. They further noted that the optimum performance of machines could be achieved at a specific range of moisture contents. It has been reported that the knowledge of thermal properties and their dependence on the moisture content are useful for the design and development of methods and equipment 
[13]. Moisture content also has a great influence in threshing, separation, cleaning and grading operations. Both theoretical and empirical relationships used when designing or operating heat processes require knowledge of the thermal properties of the material under consideration. Data on the thermal properties of various grains are widely available, but relatively few data are available for PA. Therefore, the present study was conducted to quantify the changes in thermal properties of PA at five different moisture content levels (4 to $20 \%$ w.b).

\section{MATERIALS AND METHODS}

\subsection{Sample Source}

About $100 \mathrm{~kg}$ of matured seeds pods of PA (Okpeye) was bought from Ogige Main Market in Nsukka, Enugu State, Nigeria. The seeds were manually removed from the pods (Figure 1), cleaned by winnowing in the wind and hand sorted to eliminate dirt, stones, immature seeds and other foreign materials. Samples of PA seeds were conditioned to obtain five different moisture contents: $4 \%, 8 \%, 12 \%, 16 \%$ and $20 \%$ (w.b). This range of moisture content was designed to include the whole range where thermal processing of PA seeds is possible. The distribution of chosen values of moisture content is uniform enough to obtain precise results. Samples of the seeds were initially weighed and dried in a forced convection oven at $105^{\circ} \mathrm{C}$ for 72 hours until desired final moisture content was reached. Once the desired moisture content was reached, samples were labeled, placed in plastic bags at a refrigerated temperature of $5^{\circ} \mathrm{C}$ in other to equilibrate for further experiment. The initial and final moisture content were determined with the standard method given by American Society of Agricultural Engineers (ASAE) [14].

\subsection{Determination of Moisture Content of Prosopis Africana Seeds}

The moisture content of the PA seeds was determined by the Association of Official Analytical Chemist (AOAC) method. An empty dish and lid was dried in an oven at $105^{\circ} \mathrm{C}$ for 72 hours and transferred to a desiccator to cool and weighed. About $5 \mathrm{~g}$ of the sample was weighed in the dish, spread uniformly, placed in the oven, and dried for 72 hours at $105^{\circ} \mathrm{C}$. After drying, the dish with partially covered lid was transferred to the desiccator to cool and reweighed. The loss in weight expressed as a percentage of the initial weight, was taken as the moisture content of the sample. The moisture content was calculated using Equation 1

$$
M C_{w b}=\frac{\left(W_{i}-W_{f}\right)}{W_{i}} \times 100
$$

Where, $M C_{w b}$ is moisture content (\%) on wet basis; $W_{i}$ is initial weight of sample (g) and $W_{f}$ is final oven-dried weight of sample (g)
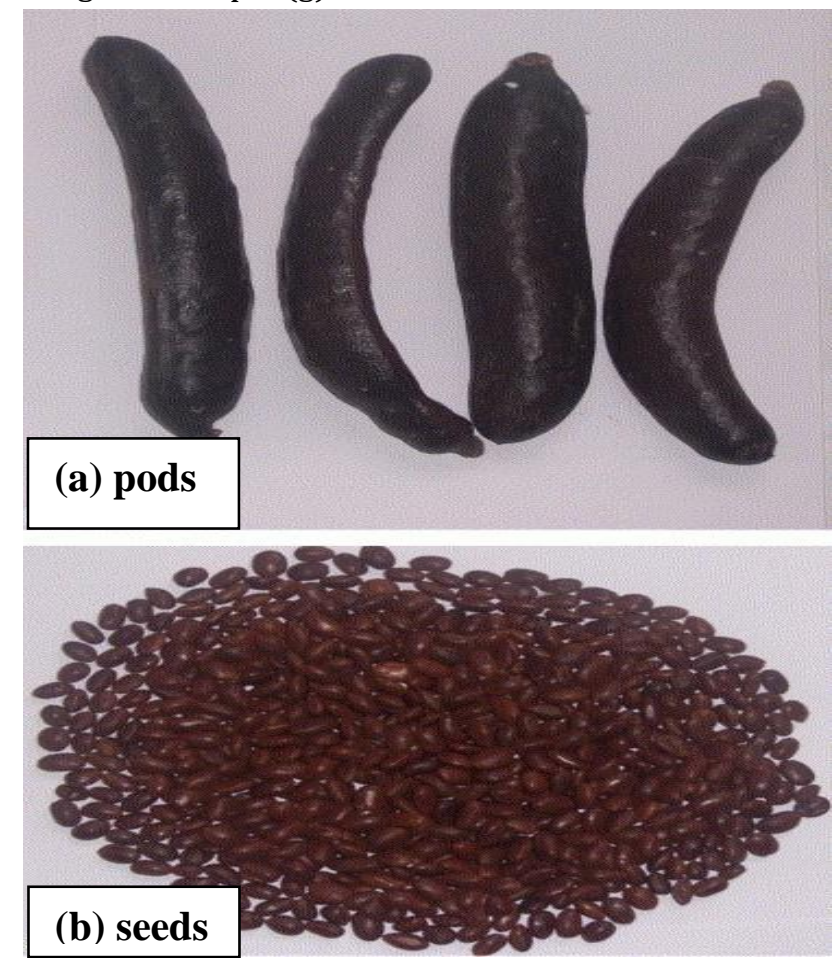

Figure 1: Prosopis Africana

\subsection{Determination of Thermal Properties of Prosopis Africana Seeds}

Determination of the thermal properties of Prosopis Africana seeds such as specific heat capacity, thermal heat conductivity, thermal heat diffusivity and bulk density are shown below:

\subsubsection{Determination of specific heat capacity of Prosopis Africana seeds}

The method of mixtures has been the most common technique reported in the literature for measuring the specific heat of agricultural and food materials due to its simplicity and accuracy $[15,16,17,18]$. This method was used for the determination of specific heat capacity of PA at various moisture levels. It involves the use of a lagged calorimeter, a digital thermometer to measure change in temperature with other heat determinant apparatus. The lagged calorimeter was calibrated using various temperatures ranging from $30-75{ }^{\circ} \mathrm{C}$. The calibration of calorimeter is necessary to minimize experimental error. The calorimeter was calibrated by pouring a certain quantity of cold water into it. The temperature of the cold water was allowed to stabilize at a given temperature before a measured quantity of hot water was added to it. The equilibrium temperature of the mixture of hot and cold water was recorded. The respective quantities of hot and cold water were adjusted 
until a final temperature of the mixture that was close to the room temperature was obtained. The energy balance equation, according to Venkata et al. [19], for the calibration of the calorimeter is given in equation $2[16$, $18,20]$.

$$
\mathrm{C}_{\mathrm{c}}=\frac{M_{h} C_{h}\left[T_{h}-\left(T_{e}+t^{1}\right)\right]}{M_{c}\left[\left(T_{e}+t^{1}\right)-T_{c}\right]}
$$

In (2) $C_{c}$ is specific heat capacity of calorimeter at mid temperature between $\left(T_{e}+t^{1}\right)$ and $T_{c}\left(\mathrm{~kJ} \mathrm{~kg}^{-1}{ }^{\circ} \mathrm{C}^{-1}\right) ; C_{h}$ is specific heat capacity of hot water at mid temperature between $T_{h}$ and $\left(T_{e}+t^{1}\right)\left(\mathrm{kJ} \mathrm{kg}^{-1}{ }^{\circ} \mathrm{C}^{-1}\right) ; M_{h}$ is mass of hot water $(\mathrm{kg}) ; M_{c}$ is mass of calorimeter $(\mathrm{kg}) ; T_{h}$ is temperature of hot water $\left({ }^{\circ} \mathrm{C}\right) ; T_{e}$ is equilibrium temperature of calorimeter and hot water $\left({ }^{\circ} \mathrm{C}\right)$ and $t^{1}$ is temperature correction $\left({ }^{\circ} \mathrm{C}\right)$. The temperature correction was calculated using equation 3.

$$
t^{1}=t_{r}{ }^{1} \theta
$$

Where, $t_{r}{ }^{1}$ is rate of temperature loss $\left({ }^{\circ} \mathrm{C} \mathrm{min}^{-1}\right)$ and $\theta$ is elapsed time (min)

The calibration was replicated five times and the quantities of hot and cold water adjusted to achieve final temperatures. The average value of the specific heat capacity of calorimeter was noted.

The apparatus for the determination of specific heat capacity of PA seed is as shown in Figure 2. The specific heat of PA seed was determined by dropping a sample of known weight (5 g), temperature (within a range of 25$30^{\circ} \mathrm{C}$ ) and given moisture content into the calorimeter containing water with known weight and temperature. The mixture was stirred continuously using a copper stirrer. The temperature was recorded at an interval of 60 s using digital thermometer. At equilibrium, the final or equilibrium temperature was noted and the specific heat capacity of PA seeds was calculated using equation 4 [17].

$$
C_{s}=\left\{\frac{\left(C_{c}+M_{h} C_{w}\right)\left[T_{h}-\left(T_{e}+t r^{1}\right)\right]}{M_{s}\left[\left(T_{e}+t r^{1}\right)-T_{s}\right]}\right\}
$$

Where, $C_{s}$ is specific heat capacity of Prosopis Africana seeds $\left(\mathrm{kJ} \mathrm{kg}^{-10} \mathrm{C}^{-1}\right) ; C_{c}$ is specific heat capacity of calorimeter $\left(\mathrm{kJ} \mathrm{kg}^{-10} \mathrm{C}^{-1}\right) ; M_{h}$ is mass of hot water $(\mathrm{kg})$;

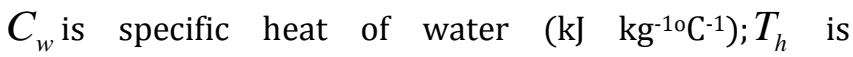
temperature of hot water $\left({ }^{\circ} \mathrm{C}\right) ; T_{e}$ is equilibrium temperature $\left({ }^{\circ} \mathrm{C}\right) ; M_{s}$ is mass of seed $(\mathrm{kg}) ; T_{s}$ is temperature of seed $\left({ }^{\circ} \mathrm{C}\right) ; t r^{1}$ account for the heat of hydration and heat of exchange with the surroundings; and $r^{1}$ is the rate of temperature rise of the mixture after equilibrium was reached.

At each moisture level, the experiment was replicated 5 times and the average values of the specific heat capacity reported.

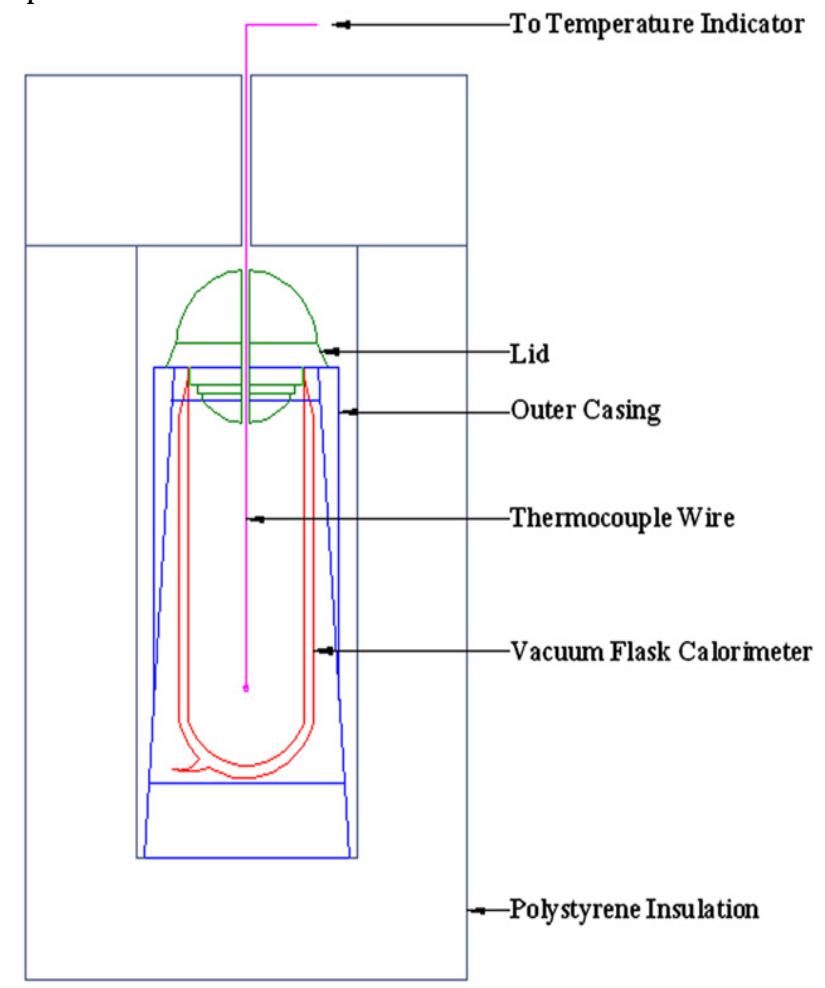

Figure 2. Sectional view of specific heat capacity experimental apparatus

\subsubsection{Determination of thermal heat conductivity of Prosopis Africana seeds}

Three major parameters must be identified in the calculation of heat transfer in food materials: thermal properties of the food, geometry of the food and thermal processing conditions [21]. Two methods can be employed in measuring thermal conductivity of biological food materials. They are: 1 . Steady state heat transfer method. 2. Unsteady state (transient) heat transfer method [22].

The thermal heat conductivity was determined by employing the method described by Aviara and Haque [16] and Mohsenin [22] using a guarded hot plate apparatus with steady-state heat flow method as shown schematically in Figure 3. It consisted of an upper (hot) plate and a lower (cold) plate, all made of mild steel. The upper plate was $90 \mathrm{~mm}$ in diameter and $30 \mathrm{~mm}$ thick. It was surrounded by a guard ring of $120 \mathrm{~mm}$ diameter and $13 \mathrm{~mm}$ thickness. The gap between the upper (hot) plate and the guard ring was filled with fiber glass at both the top of the plate and the sides to a thickness of $10 \mathrm{~mm}$. The lower plate had a diameter of $90 \mathrm{~mm}$ and a thickness of $9 \mathrm{~mm}$. 


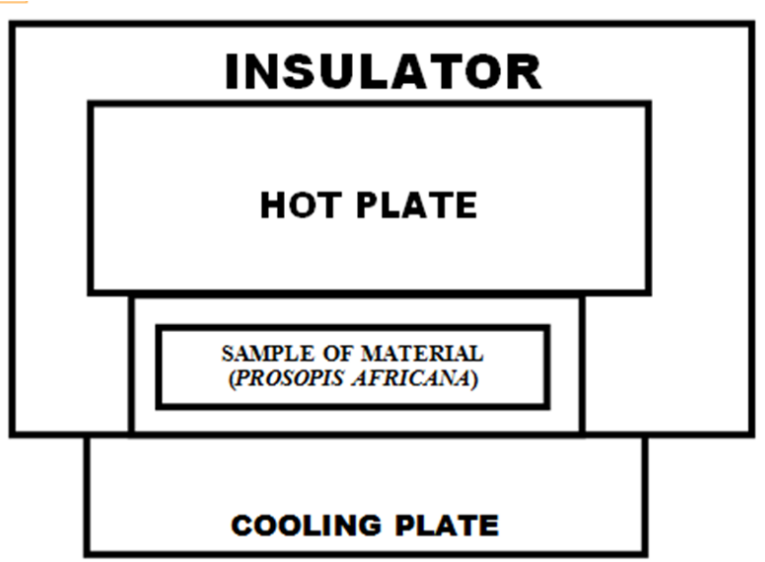

Figure 3. Schematic diagram of guarded hot plate for measurement of thermal heat conductivity

It was surrounded by a wooden guard ring of $125 \mathrm{~mm}$ diameter and $14 \mathrm{~mm}$ thickness, from which it will be separated by fiber glass to a thickness of $14 \mathrm{~mm}$. The upper plate was heated electrically and this was controlled using a variable voltage regulator. Measurements of current and voltage were made using a multi-meter. The temperature of the plates was measured with a digital thermometer at the heat source and heat sink respectively. The heat flux of the thermal heat conductivity apparatus was obtained using samples of known thermal conductivity, which was also used to calibrate the equipment. The thermal heat conductivity of PA seed was computed from the temperature changes and heat flux obtained for known thermal conductivity using a sample at specified moisture content which was cut into a regular shape as represented in Figure 4.

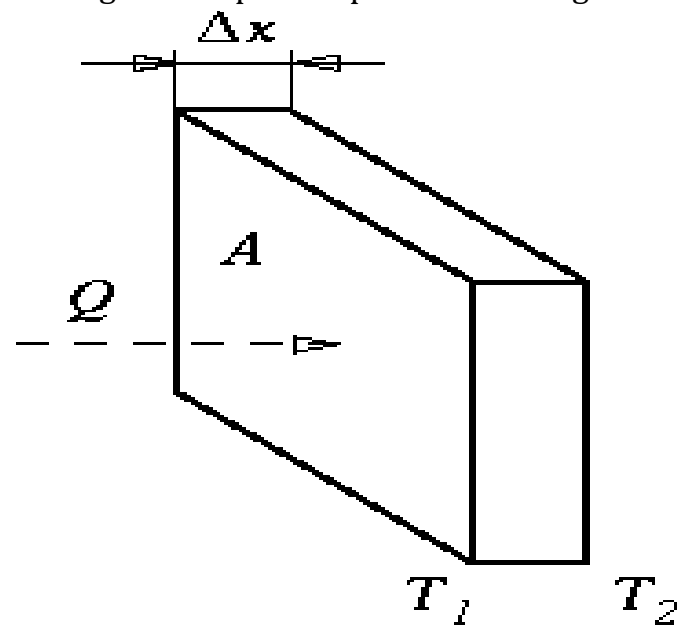

Figure 4. Conduction of heat transfer process through surfaces with different temperature, Source: Modi et al. [21].

The heat source was adjusted to maintain a temperature range of $61-64^{\circ} \mathrm{C}$. At the equilibrium condition or steady state condition, the temperature difference was recorded and used in calculating the thermal conductivity of the sample using equation 5 .

$$
K=\frac{Q\left(X_{2}-X_{1}\right)}{A\left(T_{2}-T_{1}\right)}
$$

In (5), $\mathrm{K}$ is thermal heat conductivity $\left(\mathrm{W} \mathrm{m}^{-10} \mathrm{C}^{-1}\right) ; Q$ is rate of heat transfer $\left(\mathrm{W} \mathrm{s}^{-1}\right) ; X_{2}$ is longer distance (m); $X_{1}$ is shorter distance (m); $A$ is area $\left(\mathrm{m}^{2}\right) ; T_{1}$ is inside hotter temperature $\left({ }^{\circ} \mathrm{C}\right)$ and $T_{2}$ is outside cooler temperature $\left({ }^{\circ} \mathrm{C}\right)$. The experiment was replicated 5 times for each of the moisture levels and the average calculated as the thermal heat conductivity.

\subsubsection{Determination of thermal heat diffusivity of Prosopis Africana seeds}

Two methods could be used for the determination of thermal diffusivity of PA seeds. They are: The mathematical method and experimental method. The mathematical method was used for the determination of thermal diffusivity of Prosopis africana seeds as it gave a more robust result. This was computed using equation 6 as reported by Fadele [23].

$$
\beta=\frac{K}{D_{b} C_{s}}
$$

In (6), $\beta$ is thermal heat diffusivity $\left(\mathrm{m}^{2} \mathrm{~s}^{-1}\right) ; K$ is thermal heat conductivity $\left(\mathrm{W} \mathrm{m}^{-10} \mathrm{C}^{-1}\right) ; D_{b}$ is bulk density $\left(\mathrm{kg} \mathrm{m}^{-}\right.$ $\left.{ }^{3}\right)$ and $C_{s}$ is specific heat capacity $\left(\mathrm{kJ} \mathrm{kg}^{-10} \mathrm{C}^{-1}\right)$. This was also computed for the five moisture content levels.

\subsubsection{Determination of bulk density of Prosopis africana seeds}

The bulk density of Prosopis Africana seeds was determined by gently pouring $15 \mathrm{~g}$ samples into a cylindrical container of known volume $\left(10 \mathrm{~cm}^{3}\right)$ while striking excess samples off the brim without compacting the seeds [24]. And gently taping the bottom of the cylinder on the lab bench several times until there is no further diminishing of the sample level after filling to the $10 \mathrm{~cm}^{3}$ mark. The weight of the sample was recorded. The bulk density was calculated using the relationship in equation 7. All experiments were replicated five times at each moisture content levels

$$
D_{b}=\frac{W}{V}
$$

Where, $D_{b}$ is bulk density of PA seeds $\left(\mathrm{Kg} \mathrm{m}^{-3}\right) ; W$ is weight of seeds $(\mathrm{Kg})$ and $V$ is volume of seeds $\left(\mathrm{m}^{3}\right)$

\subsubsection{Statistical analyses of data}

A $4 \times 5$ factorial in Completely Randomized Design (CRD) experimental design with a total of 100 observations (4 levels of thermal properties $\times 5$ levels of moisture content $\times 5$ replications) was conducted. Data were 
analyzed using descriptive and inferential statistics with GENSTAT RELEASE 10.3 DE( PC/Windows 7) and Excel packages. Analysis of variance (ANOVA), F-test and LSD were carried out to test the effect of moisture content (4 to $20 \%$ w.b) on thermal properties and bulk density.

\section{RESULTS AND DISCUSSION}

\subsection{Thermal Properties}

Table 1 show the result of the effect of moisture content on thermal properties and bulk density of Prosopis africana seeds (Okpeye) using Least Significant Difference (LSD) format. Results of the tests show that moisture content has significant effect $(p<0.05)$ on all the thermal properties and bulk density considered.

\subsubsection{Specific heat capacity}

Variation of specific heat capacity with moisture content is presented in Figure 5. The specific heat capacity varied from $2760 \mathrm{Jkg}^{-1}{ }^{\circ} \mathrm{C}^{-1}$ to $2960 \mathrm{~J} \mathrm{~kg}^{-1}{ }^{\circ} \mathrm{C}^{-1}$ when moisture content varied from 4 to $20 \%$ (w.b). The specific heat capacity increased with increasing moisture content. The increasing trend in specific heat capacity with moisture content correlates with the works done by other researchers. Nathakaranakule and Prachayawarakorn
[25] found a linear relationship of specific heat capacity of cashew nuts with moisture content. Hsu et al. [26] reported that the specific heat capacity of pistachios varied from 1.1 to $2.1 \mathrm{~kJ} \mathrm{~kg}^{-1}{ }^{\mathrm{o}} \mathrm{C}^{-1}$ within the moisture content range of $9.5-39 \%$ (d.b.).Chandrasekar and Viswanathan [27] studied the thermal properties of two varieties of coffee beans in the moisture content ranges of $9.9-30.05 \%$ (d.b.) and showed that specific heat capacity increased linearly from 0.78 to $2.36 \mathrm{~kJ} \mathrm{~kg}^{-1}{ }^{\mathrm{o}} \mathrm{C}^{-1}$ with increasing moisture content. Mutara etal. [28] reported an increase in specific heat capacity with moisture content from 1506.81 to $2457.15 \mathrm{~J} \mathrm{~kg}^{-1}{ }^{\mathrm{o}} \mathrm{C}^{-1}$ for lentil seeds. However saponaria vaccaria seeds showed an ascending-descending trend [29]. Other studies have reported non-linear relationships of specific heat capacity with moisture content of some food and agricultural products $[15,16,30,31]$.

The specific heat capacity of PA gave the highest value at a moisture content of $20 \%$ w.b which were significantly different from $4 \%, 8 \%, 12 \%$ and $16 \%$ respectively $(\mathrm{p}<0.05)$. At $8 \%$ and $16 \%$ the specific heat capacity of PA seeds are statistically significant. At other levels of moisture content, they are statistically different also (statistically significant) from each other (Table 1).

Table 1: Variation of thermal properties and bulk density with moisture content of Prosopis africana seeds (Okpeye) using Least Significant Difference (LSD) format.

\begin{tabular}{ccccc}
\hline \multirow{2}{*}{$\begin{array}{c}\text { Moisture Content } \\
(\%)(\text { w.b })\end{array}$} & $\begin{array}{c}\text { Specific heat Capacity } \\
\left(\mathrm{J} \mathrm{kg}^{-1} \mathrm{C}^{-1}\right)\end{array}$ & $\begin{array}{c}\text { Thermal heat conductivity } \\
\left(\mathrm{W} \mathrm{m}^{-1} \mathrm{C}^{-1}\right)\end{array}$ & $\begin{array}{c}\text { Thermal heat } \\
\text { Diffusivity }\left(\mathrm{m}^{2} \mathrm{~s}^{-1}\right)\end{array}$ & $\begin{array}{c}\text { Bulk density } \\
\left(\mathrm{kg} \mathrm{m}^{-3}\right)\end{array}$ \\
\cline { 2 - 5 } & 2760 & 0.70 & $2.7 \times 10^{-7}$ & 890 \\
8 & 2820 & 0.71 & $3.5 \times 10^{-7}$ & 710 \\
12 & 2890 & 0.73 & $3.7 \times 10^{-7}$ & 704 \\
16 & 2910 & 0.85 & $3.9 \times 10^{-7}$ & 640 \\
20 & 2960 & 0.90 & $4.2 \times 10^{-7}$ & 590 \\
Standard Error & 4.47 & 0.0447 & $1.9 \times 10^{-9}$ & 9.08 \\
LSD $_{0.05}$ & 9.33 & 0.0933 & & 18.94 \\
\hline
\end{tabular}

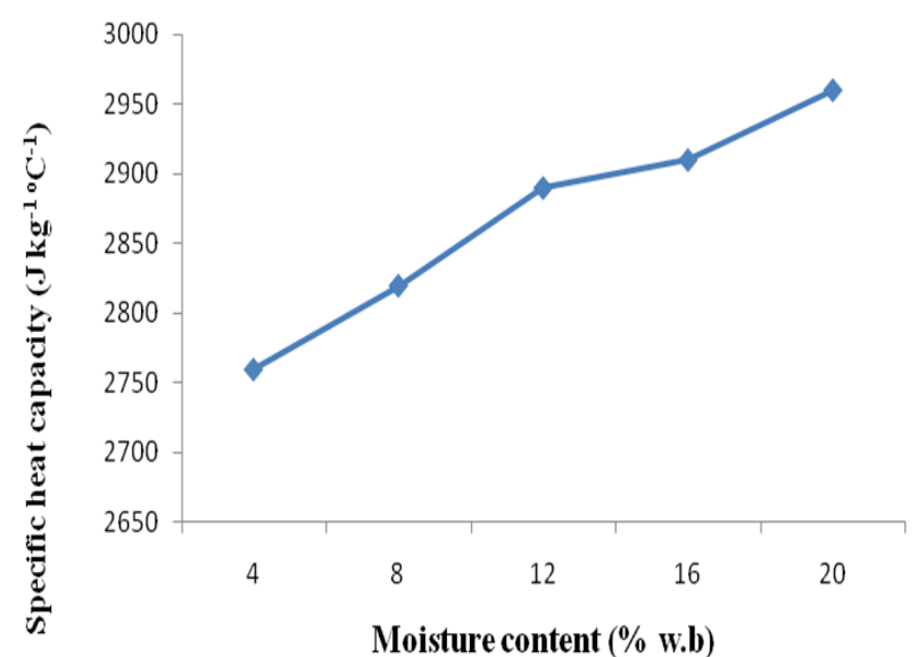

Figure 5. Variation of specific heat capacity with moisture content of Prosopis africana seeds (Okpeye)

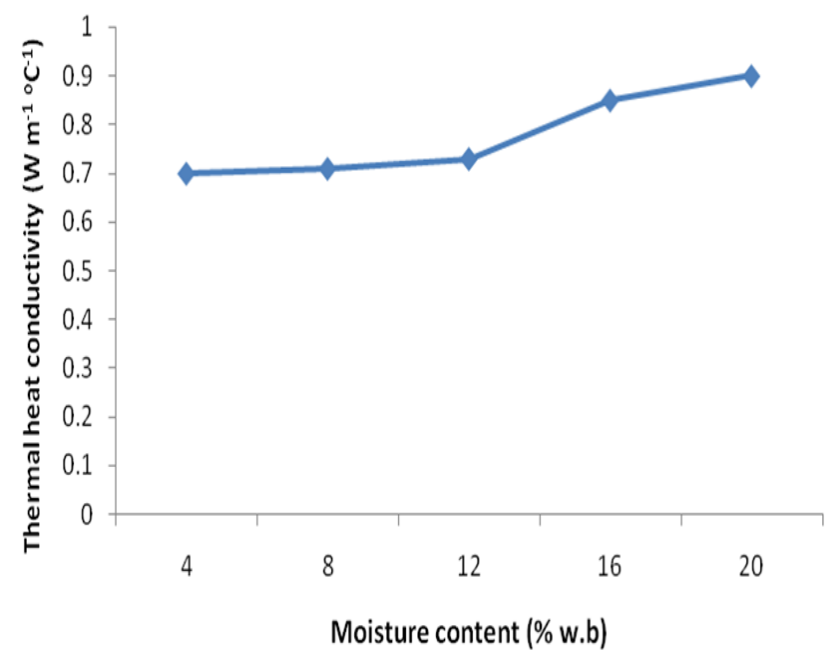

Figure 6. Variation of thermal heat conductivity with moisture content of Prosopis africana seeds (Okpeye) 


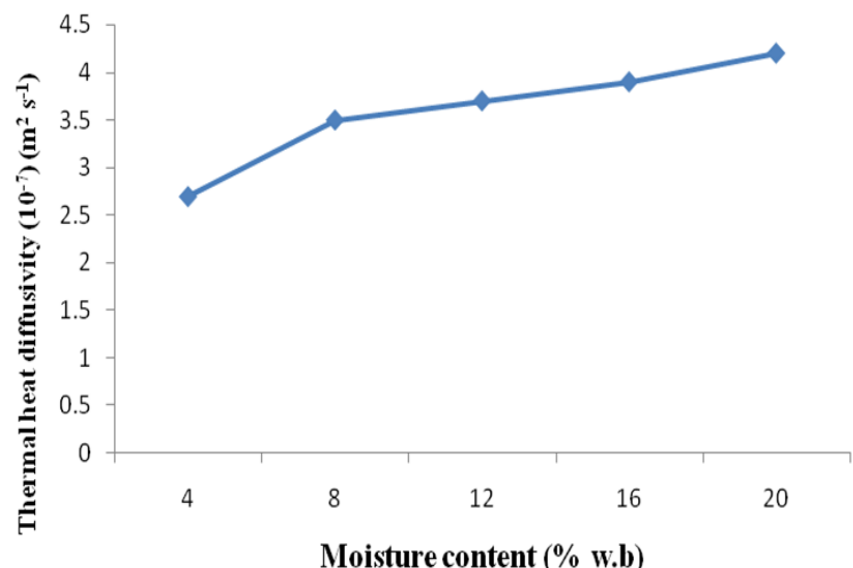

Figure 7. Variation of thermal heat diffusivity with moisture content of Prosopis africana seeds

\subsubsection{Thermal heat conductivity}

Variation of thermal heat conductivity with moisture content is presented in Figure 6. The thermal heat conductivity of PA seeds increased significantly by $28.6 \%$ from 0.70 to $0.90 \mathrm{~W} \mathrm{~m}^{-1}{ }^{\circ} \mathrm{C}^{-1}$ as moisture content increased from 4 to $20 \%$ (w.b). Values of thermal heat conductivity determined in this investigation was not different from thermal heat conductivities of agricultural products reported by other researchers. Saponaria vaccaria seeds showed an increased in thermal heat conductivity (15.35 to $80 \%$ d.b.) [29].Two accessions of African yam beans (sphenostylis stenocarpa) studied,exhibited an increase in thermal heat conductivity from 0.2097 to $0.3065 \mathrm{~W} \mathrm{~m}^{-10} \mathrm{C}^{-1}$ as moisture content increased from 4 to $16 \%$ (d.b.) [32]. Yu et al. [33] reported an increase in thermal heat conductivity from 0.06 to $0.162 \mathrm{~W} \mathrm{~m}^{-10} \mathrm{C}^{-1}$ for stored bulk canola seed within moisture content range of 7.13 to $17.46 \%$ (d.b.).Kara et al. [34], Ikegwu and Ezeh[35] and Ravikanth et al. [36] also reported linear increase in the thermal heat conductivity for red lentil seeds, kerstingiella geocarpa seeds and mung bean seeds respectively. The thermal heat conductivity of PA seed is lowest at $4 \%$ (w.b) moisture content which statistically is significantly different $(\mathrm{p}<0.05)$ from $8 \%, 12 \%, 16 \%$ and $20 \%$ (w.b) respectively. At all levels of moisture content $(4 \%, 8 \%, 12 \%, 16 \%$ and $20 \%$ w.b), thermal heat conductivity are statistically different (statistically significant) from each other (Table 1)

\subsubsection{Thermal heat diffusivity}

Variation of thermal heat diffusivity values with moisture content is shown in Figure 7. Thermal heat diffusivity of PA increased from $2.7 \times 10^{-7}$ to $4.2 \times 10^{-7} \mathrm{~m}^{2} \mathrm{~s}^{-1}$ with increasing moisture content from 4 to $20 \%$ (w.b). This indicates the ability of the PA seed to retain heat when processed. The thermal heat diffusivity of PA seed is lowest at $4 \%$ (w.b), increased by $55.6 \%$ as moisture content rose to $20 \%$. Thermal heat diffusivity values at

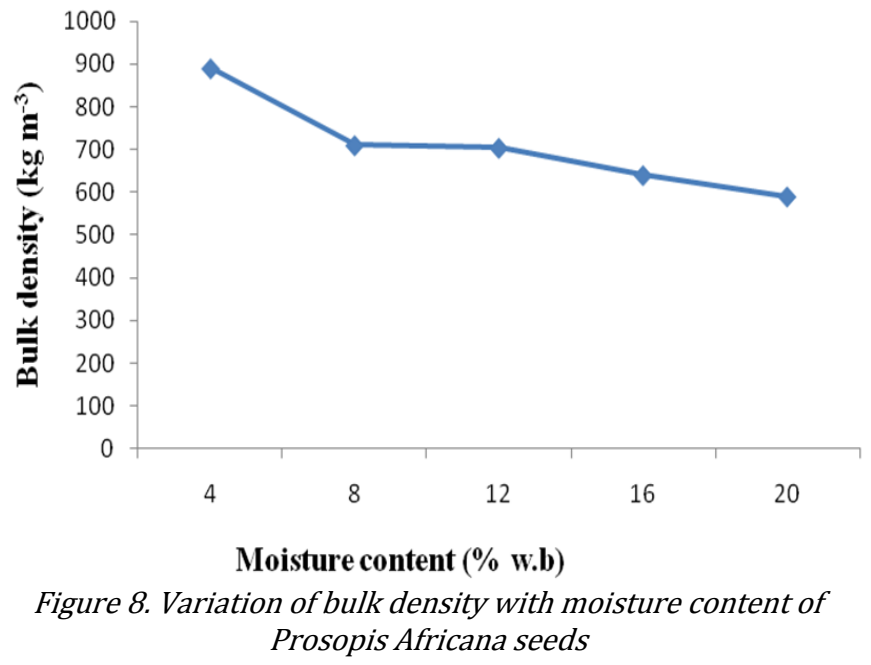

$20 \%$ (w.b) moisture content is significantly different from $4 \%, 12 \%, 16 \%$ and $20 \%$ (w.b) respectively $(\mathrm{p}<0.05)$. At $4 \%, 8 \%, 12 \%, 16 \%$ and $20 \%$ (w.b) moisture content, the thermal heat diffusivity of PA seeds are significantly different from each other (Table 1 ).

\subsubsection{Bulk Density}

Figure 8 shows variation of bulk density of PA seeds with moisture content. Values of bulk density of PA seeds with moisture content decreased from $890 \mathrm{~kg} \mathrm{~m}^{-3}$ to $590 \mathrm{~kg} \mathrm{~m}$ ${ }^{3}$ when the moisture content increased from 4 to $20 \%$ (w.b). Akaaimo and Raji [37] had earlier obtained a bulk density and true density values of 899.67 and $1397.10 \mathrm{~kg}$ $\mathrm{m}^{-3}$ respectively for PA seeds. The decrease of bulk density with moisture content of PA seeds is mainly due to the fact that moisture of grains in the sample was lower than accompanying volumetric expansion of the seeds [38]. The decrease in bulk density of PA seed with increase in moisture content indicates that the increase in volumetric expansion in the seed is greater than weight. Some other grains showed the same trend, such as fenugreek seed, vetch seed [38], and cowpea seed [39]. Balasubramanian [40] found the bulk density of raw cashew to decrease linearly with increasing moisture content. Negative linear relationship of bulk density with moisture content was also observed by Kibar et al. [41] for forrice, Seifi and Alimardani[42] for corn and Gupta and Das [43] for sunflower seed.

PA has the highest bulk density at moisture content of $4 \%$ (w.b) which is significantly different from $8 \%, 12 \%$, $16 \%$ and $20 \%$ (w.b) respectively $(\mathrm{p}<0.05)$. At $8 \%$ and $12 \%$ the bulk densities of PA seeds are not significant. They are statistically equal while at other levels of moisture content, they are statistically different from each other.

\section{CONCLUSIONS}

Experimental investigations have been carried out in order to investigate some moisture dependent thermal 
properties and bulk density of Prosopis africana (Okpeye) seeds. From the results, it was found that bulk density of Prosopis africana seeds decreased from 890 to $590 \mathrm{~kg} \mathrm{~m}^{-3}$ with increasing moisture content from 4 to $20 \%$ (w.b).The specific heat capacity increased significantly from 2760 to $2960 \mathrm{~J} \mathrm{~kg}^{-1}{ }^{\mathrm{o}} \mathrm{C}^{-1}$ with increasing moisture content.The thermal heat conductivity of PA seeds increased from 0.70 to $0.90 \mathrm{~W} \mathrm{~m}^{-10} \mathrm{C}^{-1}$ with increase in moisture content from 4 to $20 \%$ (w.b). Thermal heat diffusivity of Prosopis africana seeds rose from $2.7 \times 10^{-7}$ to $4.2 \times 10^{-7} \mathrm{~m}^{2} \mathrm{~s}^{-1}$ as moisture content increased from 4 to $20 \%$ (w.b). Investigation of the thermal properties and bulk density of PA seeds showed that the results of the test is in good agreement with some of the general trend and ranges obtained for other similar crops. The results obtained will be useful in the future for development of drying, aeration and storage systems of PA seeds.

\section{REFERENCES}

[1] Keay, R.W.J., Onochie, C.F.A. and Stan Field, “D.P. I", Vol II. Federal Forestry Research, Ibadan, Nigeria, 1964, pp 113-114.

[2] Agboola, D.A. "Studies on seed dormancy of selected economic tropical forest tree species". Nigerian Journal of Botany 4:115-126. 1995.

[3] Fasidi, I.O., Samani, T., Kadiri, M. and Agboola, D.A."Dormancy types and water uptake in seeds of Parkiabiglobosa. Journal of Natural and Applied Sciences, 1, 14-20. 2000

[4] Spore, C.T.A. "The Prosopis species". Bulletin of the Technical Centre for Agricultural and Rural Cooperation (Wagenigen, the Netherlands), 48, pp 6, 1993

[5] Ola-Adams, B.A. and Onyeabusim, H.D. "Conservation and utilization of endangered edible wild plants in Nigeria". In Proceedings of the Seminar on Lost Crops of Nigeria, University of Agriculture, Abeokuta, Nigeria, pp 33-43. , 1993.

[6] Okafor, J.C. "Lost crops of Nigeria: In Proceedings of the Seminar on Lost Crops of Nigeria". University of Agriculture, Abeokuta, Nigeria, 1993, pp 221.

[7] Ayanwuyi, L.O., Yaro, A.H. and Abodunde, O.M. "Analgesic and anti-inflammatory effects of methanol stem bark extract of Prosopis Africana". Pharmaceutical Biological, 48, 3(2010) 296-299.

[8] Amusa, T.O., Jimoh, S.O., Aridanzi, P. and Haruna, M.A. "Ethnobotany and conservation of plant resources of kainji lake national park, Nigeria".Ethnobotany Research and Application, 8 (2010) 18-194.

[9] Diagne, 0.“Current development on Prosopisspecies in Senegal: In Prosopis species:
Aspects of their values, research and development". Centre for Overseas Research and

Development, University of Durham, Durham, UK. 1992, pp 47-59

[10] Alabi. D.A."Parkiabiglobosa: An endangered species. In Proceedings of the Seminar on Lost Crops of Nigeria". University of Agriculture Abeokuta, Nigeria. (1993) pp 265-285.

[11] Kachru, R.P., Gupta, R.K. and Alam, A. PhysicoChemical Constituents and Engineering Properties of Food Crops. Jodhpur, India: Scientific Publishers (1994).

[12] Aviara, N.A., Gwandzang, M.I. and Haque, M.A. "Physical properties of guna seeds".Journal of Agricultural Engineering Research, 73 (1999) 105111.

[13] Visvanathan, R., Palanisamy, P.T., Gothandapani, L. and Sreenarayanan, V.V. "Physical properties of neem nut". Journal of Agricultural Engineering Research, 63 (1996) 19-36.

[14] ASAE. Standard Engineering Practices , 43rd ed., Data S352.2. (Dec. 1997). St. Joseph, Mich.: ASAE (1996).

[15] Singh, S.S. and Goswani, T.K. "Thermal properties of cumin seed". J Food Eng., 45 (2000) 181-187.

[16] Aviara, N.A. and Haque, M.A. "Moisture dependence of thermal properties of sheanut kernel”. J. Food Eng.,. 47, 2 (2001) 109-113.

11] NouriJangi, A., Mortazavi, S.A., Tavakoli, M., Ghanbari, H., Tavakolipour, A. and Haghayegh, G.H. "Comparison of mechanical and thermal properties between two varieties of barley (Hordeumvulgare L.) grains ". Aust J. Agric. Eng., 2, 5 (2011) 132-139.

[18] Desphande, S.D., Bal, S. and Ojha, T.P. "Bulk thermal conductivity and diffusivity of soybean". J. Food Proc. and Preserv., 20, 3 (1996) 177-189.

[19] Venkata, S.P.B., Shamina, B., Ramakrishna, P., Narender, G. and Womac, R.W.A. "Moisture dependent thermal properties of peanut pods, kernels, and shells".Biosystems engineering, 106 (2010) 503-512.

[20] Razavi, S.M.A. and Taghizadeh, M. "The specific heat of pistachio nuts as affected by moisture content, temperature, and variety". J. Food Eng., 79 (2007) 158-167.

[21] Modi, S.K., Durga, P.B. and Basavaraj, M. "Effect of moisture content and temperature on thermal conductivity of Psidium guajavaL. by line heat source method (transient analysis)". International Journal of Heat and Mass Transfer 78 (2014) 354359.

[22] Mohsenin, N. N. Thermal Properties of Food and Agricultural Materials. Gordon and Breach Press, New York, USA (1980). 
[23] Fadele,. O.K. Determination of Some Engineering Properties of Doum Palm Fruit (Hyphaenethebaica). Unpublished MSc. Thesis. University of Ibadan, (2010).

[24] Zewdu, A.D. and Solomon, W.K. "Moisture dependent physical properties of tef seed". Biosystem Engineering, 96, 1 (2007) 57-63.

[25] Nathakaranakule, A. and Prachayawarakorn, S. "Determination of physical properties of cashew nuts". J. Kasetsart, 32, 2 (1998) 171-186.

[26] Hsu, M.H., Mannapperuma, J.D. and Singh, R.P. "Physical and thermal properties of pistachios". J. Agric. Eng. Research 49, 4 (1991) 311-321.

[27] Chandrasekar, V and Viswanathan, R. "Physical and thermal properties of coffee". J Agric. Eng. Res., 73 (1999) 227-234.

[28[ Murata, S., Tagawa, A. and Ishibashi, S."The effect of moisture content and temperature on specific heat of cereal grains measured by DSC". J Jap Soc. Agric Mach, 46, 6 (1995) 547-554.

[29] Shrestha, B.L. and Baik, O.D. "Thermal conductivity, specific heat, and thermal diffusivity of saponaria vaccaria seed particles". Transactions of the ASABE 53, 5 (2010) 1717-1725.

[30] Chakraborty, S.M. and Johnson, W.H. "Specific heat of flue cured tobacco by differential scanning calorimeter". ASAE., 15, 5 (1999) 928-931.

[31] Solomon, W.K. and Zewdu, A.D. "Moisture dependent physical properties of Niger (GuiconiaabyssinicaCass.) seed". Ind. Crops and Prod., 29 (2009) 165-170.

[32] Irtwange, S.W. and Igbeka, J.C. "Effect of moisture content and power input on thermal conductivity of African yam bean (sphenostylis stenocarpa)". Transactions of the ASAE, 45, 5 (2002) 14751478.

[33] Yu, D.U., Shrestha, B.L. and Baik, O.D. " Thermal conductivity, specific heat, thermal diffusivity, and emissivity of stored canola seeds with their temperature and moisture content". Journal of Food Engineering 165 (2015) 156-165.

[34] Kara, M., Boydas, G., Kara, Y.A. and Ozturk, I. “The effect of moisture content on the thermal properties of red lentil seeds". Transactions of the $A S A B E, 55,6$ (2012) 2301-2306.

[35] Ikegwu, O.J. and Ezeh, C.Q. "Thermal properties of Kerstingiella geocarpa seeds as influenced by moisture Content". Official Journal of Nigerian Institute of Food Science and Techonology, 30, 2 (2012) $100-105$.

[36] Ravikanth, L., Jayas, D.S., Alagusundaram, K. and Chelladurai, V. "Measurement of thermal properties of mung bean (vigna radiata)". Transactions of the American Society of Agricultural and Biological Engineers (ASABE), 55,6 (2012) 2245-2250.

[37] Akaaimo, D.I. and Raji, A.O. "Physical and engineering properties of Prosopis africana seed". Biosystems Engineering, 95, 2 (2006) 197-205.

[38] Yalcin, I and Özarslan, C. "Physical properties of vetch seed”. Biosyst. Eng., 89, 4 (2004) 507-512.

[39] Yalcin, I."Physical properties of cowpea (Vignasinensis L.) seed”. J. Food Eng., 79 (2007) 57-62.

[40] Balasubrahumanian, D. "Physical Properties of raw cashew nut". J Agric. Eng. Res. 78, 3 (2001) 291297.

[41] Kibar, H., Ozturk, T. and Esen, B. "The effect of moisture content on physical and mechanical properties of rice (Oryzasativa L.)”. Spanish J. Agric. Res., 8, 3 (2010) 741-749.

[42] Seifi, M.R. and Alimardani, R. "Comparison of moisture dependent physical and mechanical properties of two varieties of corn (Sc 704 and Dc 370)”. Aust J Agric. Eng., 1,5 (2010).170 -178.

[43] Gupta, R.K. and Das, S.K. "Some physical properties of sunflower". J. Food Eng., 66 (1997) 1-8. 